\title{
Using Forest Resources for Economic Development and Poverty Reduction in Ekiti State
}

\author{
Emmanuel Rotimi Adegboyega ${ }^{*}$, Akintan Oluwakemi Bolanle \\ Department of Geography and Planning Science, Ekiti State University, Ado-Ekiti, Nigeria
}

Email address:

adeolurotimi1@yahoo.com (E. R. Adegboyega)

${ }^{*}$ Corresponding author

To cite this article:

Emmanuel Rotimi Adegboyega, Akintan Oluwakemi Bolanle. Using Forest Resources for Economic Development and Poverty Reduction in Ekiti State. International Journal of Applied Agricultural Sciences. Vol. 7, No. 4, 2021, pp. 183-189. doi: 10.11648/j.ijaas.20210704.17

Received: July 10, 2021; Accepted: July 24, 2021; Published: August 23, 2021

\begin{abstract}
Forest products are resources of immense benefits to all especially, for the people of Ekiti being an agrarian society. In the recent time, forest products are becoming poverty reduction strategy in this part of the world. The major factors responsible for this activity include the desire for food, food security, meeting household level needs, provision of raw materials, source of foreign exchange and income as well as save physical money to meet up both household demands and foreign earning. Some of the opportunities and challenges faced are the availability of land, capital and purpose for which forest products are made available for use. Questionnaire were used to collect information on the socio-economic characteristics of the respondents, various forms of forest products, their uses and services in the study area. The study found out that forest products are means of livelihood for providing food, fuel wood, fresh water protection, provision of bush meat and herbal medicine. For herbal medicine products as alternative medicine to pharmaceutical products in the society for curing the new found ailments and sicknesses. It also revealed that care must be taken to prevent deforestation, environmental degradation as well as ecological devastation in the study area. The result of the spatial tree analysis showed that unwanted destruction should be prevented so as to alleviate poverty in the study area because the inhabitants as well as the country derive means of livelihoods from the forest reserves.
\end{abstract}

Keywords: Economic Development, Ekiti State, Forest Products, Poverty Reduction, Services and Sustainability

\section{Introduction}

Forests as one of the environmental resources are large tracts of land covered with trees and other plants growing close together in its natural state. They remain in a relatively fixed, self-regulated condition over a period of time, and provide habitats for diverse animal species and their products form source of different human settlements $[9,20,17,11]$. Forests essentially support life on earth by absorbing carbon dioxide and releasing oxygen, thereby maintaining balance in the gaseous atmosphere and in the completion of water (hydrological cycle) for rainfall formation.

Forest products provide source of energy wood-fuel and charcoal (biomass energy sources of food, timber and herbal medicine for man $[15,11]$. In addition, forests play protective role against soil erosion, drought, wind breaker, flood and intense radiation. The current forest resources and their products must therefore meet both the present nation building and development as well as sustain the future generation. Thus, the issue of clearing forest for agriculture, mechanized farming, overgrazing, wildlife, charcoal production and overexploitation of wood resources for timber and poles, require geospatial information and analysis in this millennium to meet the Sustainable Development Goals (SDGs) [12]. The extraction of timber for wood fuel accounts for $61 \%$ of total wood removals in recent time [7]. Statistics revealed that Nigeria has lost over 40,000 hectares of land to agriculture and urbanization which has a greater impact on the nations land resources [22]. Studies on charcoal production in Nigeria and even in Ekiti State reveal that the end product of all these development is deforestation on our land [10]. Ekiti State falls within the tropical rainforest but the northern part of it falls within the guinea savannah (tropical savannah) that is characterized with thick forest which makes production of charcoal/wood fuel products possible in the study area. The noble idea of making forest product possible and available 
and common in the rural areas but the rural people do not normally use them but sell these products out to the people of urban settings because they are poor and would want to alleviate their level of poverty by bringing them for sales in the public, thus, the products are found majorly in the urban settings where there are markets for the products [5]. Even though most people in the rural settings, as well as low income class in the urban areas preferred forest products such as charcoal or firewood because they are available and less expensive for common man. The issue of poverty reduction and alleviation have been addressed by a number of scholars in Nigeria $[18,23,1]$ which have not yielded the desired results. Some of them pointed out the various idea experimented by government such as Operation Feed the Nation (OFN), Structural Adjustment Programmes (SAP) and Green Revolution (GR). The overarching aim was that investment in human capital are best and necessary instruments for nations development and subsequently address poverty $[16,18,8,19]$, opined that the most effective strategy to address and alleviate poverty could probably be channeled through Non-Governmental Organisation (NGOs), Community Participatory Programmes (CPP) and Self-help Programmes, (SP) of which forests and their products should serve as one of the keys to Environmental Conservation and National Development in Nigeria. However, altering forest vegetation [4] clearing of forest trees for agriculture, overgrazing, wildlife charcoal production and over exploitation of wood resources for timber and pole is at an alarming rate $[24,22]$ lamented that Nigeria had lost $21 \%$ of its forest reserves because man is a 'Homo vandalus' species in his quest for development. Ekiti State's ecoonomy is hinged on the natural resource within her environment and because of this, forest is at a greater risk of over exploitation. The over-exploitation comes as a result of ignorance and this called for sustainable forest resources management. The aim of this study therefore is to explore the geospatial information that could be used to address the issue of sustainable forests and their products as a strategic way of reducing poverty in Ekiti State. The study also examined the different types of forests, their products and spatial distribution for domestic activities in the study area. The ecological/economic benefits of the forest and the strategies capable of improving afforestation and reducing overexploitation were as well investigated.

\section{Methodology}

\subsection{The Study Area}

Ekiti State is located in the south western part of Nigeria. It lies between latitudes $07^{\circ} 15^{\prime}$ ' and $08^{\circ} 5^{\prime}$ north and between longitudes $04^{\circ} 45^{\prime}$ and $05^{\circ} 45^{\prime}$, east. The state is bounded in the north by Kwara State, in the north east by Kogi State, in the west by Osun State and in the south and south east by Ondo State (Figure 1). Ekiti State has sixteen Local Government Areas (Figure 2).

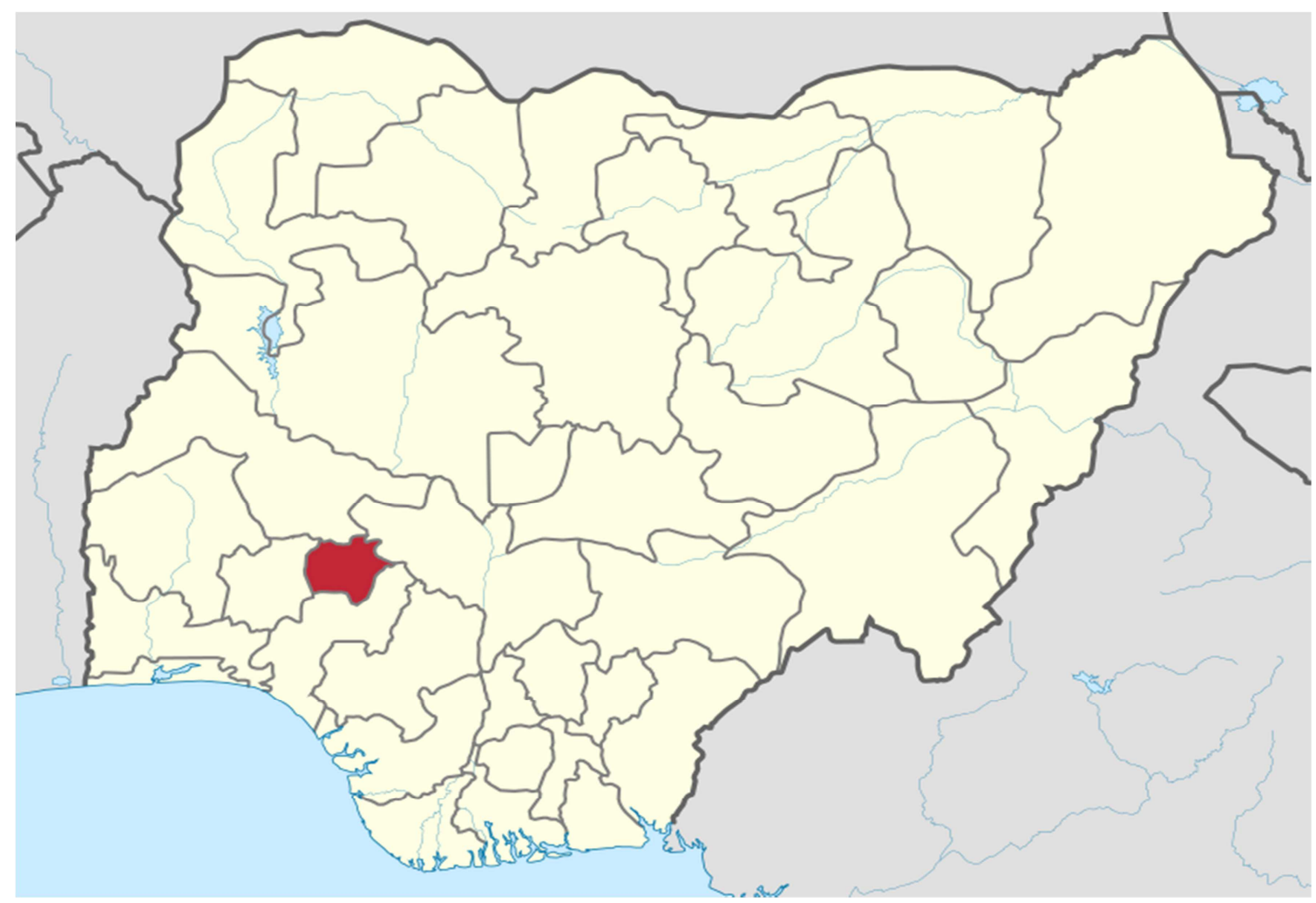

Source: Google map, 2021

Figure 1. Map of Nigeria showing Ekiti State. 


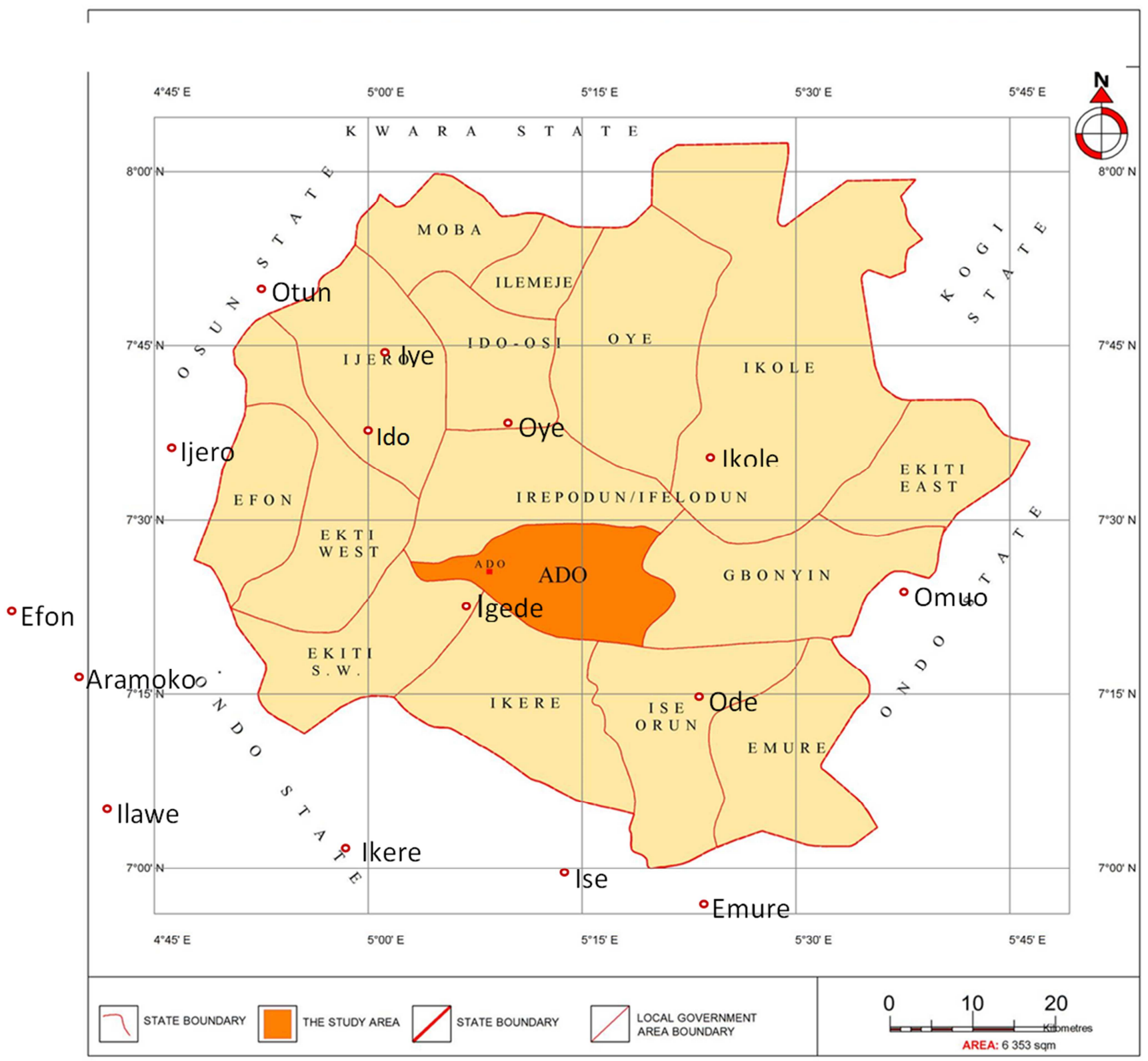

Source: Office of Surveyor-General, Ekiti State, 2017

Figure 2. Map of Ekiti State and its Local Government Areas.

The relief of Ekiti State is most gently undulating landscape rock outcrops that are part of Yoruba hills referred to as Western upland of Nigeria. This major landform characterized the whole Ekiti land and oftentimes serve as determinant factor for its use whether for economic activities such as forest exploitation or agriculture [13]. Ekiti State enjoys the humid tropical climate of distinct wet and dry seasons. The seasons are determined by the movement of the Inter-Tropical Discontinuity (ITD). The wet season spreads between April and October with the tropical maritime $(\mathrm{mT})$ air mass originating from the Atlantic Ocean. The dry season spread between November and March with the Tropical Continental (cT) air mass originating from the Sahara desert. The temperature ranges from $26^{\circ} \mathrm{C}$ to $30^{\circ} \mathrm{C}$ with the annual temperature of $27^{\circ} \mathrm{C}$ owing to the climate change experienced in the recent time.

The vegetation of Ekiti State shows that its spatial distribution varies with fascinating scenery. It is classified into two viz: the north and the south vegetation. The south falls in to the tropical low land rainforest zone of Nigeria and it is characterized by the assemblage of plant species arranged in distinctive complex vertical structure of forest canopies with a peculiar physiognomy trees include locust beans, shear butter trees [2].

\subsection{Data Collection}

In carrying out forest assessment in the study area, data were collected through the use of both primary and secondary sources. The primary data source includes data on the numbers of forest products in Ekiti State, their uses and 
services, possible reasons for the wanton destructions of the state's forest resources and the consequences of overexploitation in the state's forest. These data were obtained through the administration of questionnaire and a-total of 578 copies of questionnaire were distributed within the state. The respondents were randomly selected within the sample populations consisting of men, women, youth and the elderly ones using purposive sampling techniques. The questionnaire was designed to gather information on the sources of food and medical/herbal products for their livelihood. The secondary source of data was by satellite remote sensing imported into the GIS environment to map out the locations of the forest reserves in the state.

\subsection{Data Analysis}

The data were analysed using descriptive statistic that include tables, frequency and percentage). In addition one way Analysis of variance [Anova) was used to assess the presence of the significant difference in the data collected.

\section{Results and Discussion}

The socio-economic characteristics of the respondents are not included [see page 1 - abstract)

Table 1. Forest and agricultural species that are as sources of food in the Study Area.

\begin{tabular}{|c|c|c|c|c|c|c|c|}
\hline $\mathbf{S} / \mathbf{N}$ & Species & Family & Common Name & Habit & Local Name & Status & Economic Importance \\
\hline 1 & Adansonia digitata & Bombacacee & Baobab & Tree & Ose & Native & Food \\
\hline 2 & Anacardium occidentale & Anacardiaceae & & Tree & & Exotic & Food \\
\hline 3 & Blighia sapida & Sapindaceae & Akee Apple & Tree & Isin & Native & Food \\
\hline 4 & Citrus sineensis & Rutaceae & Sweet Orange & Tree & Osan & Exotic & Food \\
\hline 5 & Cocos nucifera & Palmae & Coconut & Tree & Agbon & Exotic & Food \\
\hline 6 & Mangifera indica & Anacardiaceae & Mango & Tree & Mangoro & Exotic & Food \\
\hline 7 & Parkia biloglobosa & Fabaceae & African locust & Tree & Iru'gba & Native & Food \\
\hline 8 & Psidium guajava & Myrtaceae & Guava & Tree & & Exotic & Food \\
\hline 9 & Elaeis guineensis jaep & Palmae & African Oil Palm & Tree & Ope & Native & Food \\
\hline 10 & Prosopis Africana & Fabaceae & Africana meanquitye & Tree & & Native & Food \\
\hline
\end{tabular}

Source: Authors' compilation, 2019

The various species of trees serving as food for consumption are shown in Table 1. Some of the species are native while some of them are introduced to the environment through agricultural process in the study area.

Table 2. Forest Tree Types that are used as timbers in the Study Area.

\begin{tabular}{|c|c|c|c|c|c|c|c|}
\hline $\mathbf{S} / \mathbf{N}$ & Species & Family & Common Name & Habit & Local Name & Status & Economic Importance \\
\hline 1 & Adansonia digitata & Bombacacee & Baobab & Tree & Ose & Native & Timber \\
\hline 2 & Afzelia Africana & Fabaceae & African Oak & Tree & mahogany & Native & Timber \\
\hline 3 & Ceibapentadra & Bambacacee & Kapok & Tree & Araba & Native & Timber \\
\hline 4 & Daniella oliveri & Fabaceae & & Tree & Obeche & Native & Timber \\
\hline 5 & Eucalyptus torelliana & Myrtaceae & River red gum & Tree & & Exotic & Timber \\
\hline 6 & Ficus muсuso & Moraceae & & Tree & & Native & Timber \\
\hline 8 & Hymenocardia acida & Euphorbaceae & Hymenocardia & Tree & & Native & Timber \\
\hline 9 & Khaya senegaelensis & Meliceee & Mahogany & Tree & Gedu & Native & Timber \\
\hline 10 & Tectona grandis & Verbenaceae & Teak & Tree & Gedu & Native & Timber \\
\hline 11 & Vitex donia & Verbenaceae & & Tree & Ori & Native & Timber \\
\hline 12 & Miliccia excels & Fabaceae & & Tree & Iroko & Native & Timber \\
\hline 13 & Mansonia altissima & Sterculiaceae & & Tree & Ofun & Native & Timber \\
\hline
\end{tabular}

Source: Authors' compilation, 2019.

Table 2 shows trees' species that are used for timber and lumbering works. Most of these species have been available for decades as native trees which are fell through spot logging and illicit practices in the study area. The trees' species are used for furniture, door and general construction; most of them are excellent hard wood for use in pleasurecrafts, especially for keels stems and panel for bridges, as well as interior fittings. The exotic ones are just been introduced and some of them are planted in individual reserves in various locations in the state. 
Table 3. Tree species that serve as Medicinal in the Study Area.

\begin{tabular}{|c|c|c|c|c|c|c|c|}
\hline $\mathbf{S} / \mathbf{N}$ & Species & Family & Common Name & Habit & Local Name & Status & Economic Importance \\
\hline 1 & Acacia quriculiformis & Mimosaceae & & Tree & Furu & Exotic & Medicinal \\
\hline 2 & Adansonia digitata & Bombacacee & Baobab & Tree & Ose & Native & Medicinal \\
\hline 3 & Afzelia Africana & Fabaceae & African Oak & Tree & Mahogany & Native & Medicinal \\
\hline 5 & Cassia fistula & Fabaceae & Cassia & Tree & & Exotic & Medicinal \\
\hline 6 & Dialium guineese & Casepiniacee & Black Tamarind & Tree & Awun & Native & Medicinal \\
\hline 7 & Ficus exasperate & Moraceae & Sandpaper & Tree & Eepin & Native & Medicinal \\
\hline 9 & Cola nitida & Stercullacee & & Tree & Obi & Native & Medicinal \\
\hline 10 & Cocus nucifera & Palmae & Coconut & Tree & Agbon & Exotic & Medicinal \\
\hline 11 & Mansonia altissima & Sterculiaceae & & Tree & Ofun & Native & Medicinal \\
\hline
\end{tabular}

Source: Authors' compilation, 2019.

Table 3 shows trees' species that are used for medicinal works. The roots, bark, leaves and fruits are used in traditional medicine. The various preparation of these plants are used for the treatment or conditions such as diabetes, malaria, aches and curbing the incidence of diet related sickness like non-chronic communicable diseases [21].

Table 4. Tree species that serve as Shades/Wind breakers in the Study Area.

\begin{tabular}{|c|c|c|c|c|c|c|c|}
\hline $\mathbf{S} / \mathbf{N}$ & Species & Family & Common Name & Habit & Local Name & Status & Economic Importance \\
\hline 1 & Acacia quriculiformis & Mimosaceae & & Tree & Furu & Exotic & Shade \\
\hline 2 & Acacia nilotica & Fabaceae & Egyptian mimosa & Tree & & Exotic & Shade \\
\hline 3 & Cassia fistula & Fabaceae & Cassia & Tree & & Exotic & Wind breaker \\
\hline 5 & Elaies guineesis & Arecaceae & Palm Tree & Tree & & Native & Shade \\
\hline 6 & Azardirachta indica & Meliaceae & Neem & Tree & Dogoyaro & Exotic & Wind breaker \\
\hline 7 & Piliostigma recticulatum & Fabaceae & Camel's foot & Tree & & Native & Wind breaker \\
\hline 9 & Pinus Caribaea & Hondura Pine & Hondura Pine & Tree & & Exotic & Wind breaker \\
\hline
\end{tabular}

Source: Authors' compilation, 2019

Table 5. Forest tree species that serve as oil and wood-fuels/charcoal production in the Study Area.

\begin{tabular}{|c|c|c|c|c|c|c|c|}
\hline $\mathbf{S} / \mathbf{N}$ & Species & Family & Common Name & Habit & Local Name & Status & Economic Importance \\
\hline 1 & Vitellaria paradoxa & Sapotaceae & & Tree & Emi & Native & Oil \\
\hline 2 & Eucalyptus torelliana & Myrtaceae & River red gum & Tree & & Exotic & Oil \\
\hline 3 & Vitex donia & Verbenaceae & Shear butter & Tree & Ori & Native & Oil \\
\hline 4 & Bauhinia monandra & Fabaceae & & Tree & & Exotic & Non -timber \\
\hline 5 & Burkea africana & Fabaceae & Burkea & Tree & & Exotic & Non- timber \\
\hline 6 & Azardirachta indica & Meliaceae & Neem & Tree & Dogoyaro & Exotic & Non- Food \\
\hline 7 & Ficus mucuso & Moraceae & & Tree & & Native & Non timber \\
\hline 8 & Ficus sur & Moraceae & & Tree & & Native & Non timber \\
\hline 9 & Gliricidia sepium & Fabaceae & & Tree & & Exotic & Non timber \\
\hline 10 & Piliostigma recticulatum & Fabaceae & Camel's foot & Tree & & Native & Non timber \\
\hline 11 & Plumeria alba & Apocynaceae & & Shrub & & Exotic & Non timber \\
\hline 12 & Polyalthia longifolia & Annonaceae & & Tree & & Exotic & Non timber \\
\hline 13 & Periscopsis laxiflora & Fabaceae & Periscopsis & Tree & & Native & Non timber \\
\hline 14 & Tamarindus indica & Fabaceae & Tamarind & Tree & & Native & Non timber \\
\hline 15 & Prosopis Africana & Fabaceae & & Tree & & Native & Non timber \\
\hline 16 & Anogeissus leiocarpus & Combretacee & [Axle wood) & Tree & Ayin & Native & Non- timber \\
\hline 17 & Acacia nilotica & Fabaceae & Egyptian mimosa & Tree & & Exotic & Non timber \\
\hline
\end{tabular}

Source: Authors' compilation, 2019

Table 5 shows the forest trees that are useful in other areas of livelihoods. Some of them are good for vegetable oil such as shear butter tree and majority of them are used for fuelwoods and for charcoal production.

Geospatial Information on Analysis of Trees

The geospatial mapping technique aids the formulation of forestry strategy. This includes sustainable development, biodiversity, land title, land tenure [cadaster], monitoring deforestation, afforestation, re-afforestation monitoring, managing commercial logging operations, watershed protection and wild life habitat assessment. In this study, GIS provides opportunities for extending the range and content of inventory and management activity of analytical tools relevant to analysis of forest resource data. GIS has great 
potential to forestry and this can be used at a range of scale such as for district, region or national, to assess, monitor, manage and plan. Use of forest resources has great value for planning and managing the integration forestry with other land uses.

Investigation revealed that majority of respondents sees the significance of forests and their products in different perspectives. Spatial analysis of different trees in the study area shows that they produce various items as listed in tables $1,2,3,4$, and 5 and their economic importance to the people for sustainable socio-economic development in the study area It also shows that trees provide many valuable products, especially timbers which were cut as wood, one of the world's chief building materials, and wood pulp used in paper making and also useful for natural herbs or traditional medicine. Wood is also a major fuel sources, trees supply, edible fruits and nuts. In addition, trees take in carbon dioxide and releases oxygen during photosynthesis, their root systems help retain water and soil preventing floods and erosion. Trees and forests provide habitats for a wide variety of animals and they beautify both natural and altered landscape.

Table 6 shows the various uses and services derivable from the forests and their products in the study area. $25.6 \%$ made use of the tree products as sources of food, $22.5 \%$ saw it as a means of providing timber for our saw mills. There are more than three hundred and sixty five Saw mills in Ekiti State [3] which serves as major industry on which the economy of the state is anchored.13.8\% of the respondents used it as a source of energy for cooking and other household uses, while $18.2 \%$ uses the products as herbs for curing various ailments and diseases. Other services are foreign exchange [11.2\%], wind breaker and soil protection [8.7\%] respectively.

Table 6. Services provided by Forest [Trees) Products.

\begin{tabular}{llll}
\hline S/N & Item & Frequency & Percentage \\
\hline 1. & Source of energy & 80 & 13.8 \\
2. & Source of foreign exchange & 65 & 11.2 \\
3. & Source of protection & 50 & 8.7 \\
4. & Source of food & 148 & 25.6 \\
5. & Source of medicine & 105 & 18.2 \\
6. & Source of timber & 130 & 22.5 \\
& Total & 578 & 100 \\
\hline
\end{tabular}

Authors' Field Work, 2019

Table 6 shows the various uses and services derivable from the forests and their products in the study area. $25.6 \%$ of the respondents see them as a source of food, $22.5 \%$ as timber, for our saw mills. There are more than three hundred and sixty five Saw mills in Ekiti State [3] which serves as major industry on which the economy of the state is anchored. $18.2 \%$ as medicinal products as herbs for curing various ailments and diseases, $13.8 \%$ as source of fuel-energy, $11.2 \%$ as foreign exchange while $8.7 \%$ considered them as shade, windbreaker or serving as protective agents. Considering the economic importance derivable from these forest products, appropriate strategy should be developed in order to promote its sustainable uses in the study area.

Table 7. Conservative measures for Forest Resources and their Products.

\begin{tabular}{llll}
\hline S/N & Item & Frequency & Percentage \\
\hline 1. & Avoiding illegal cutting & 48 & 8.3 \\
2. & Deforestation & 106 & 18.3 \\
3. & Reforestation & 152 & 26.3 \\
4. & Tree planting & 183 & 31.7 \\
5. & Environmental auditing & 89 & 15.4 \\
& Total & 578 & 100 \\
\hline
\end{tabular}

Authors' Field Work, 2019.

Table 7 shows conservative measures for Forest Resources and their Product shows that considering the economic importance derivable from these forest products, appropriate conservative measures to take were sampled from the respondents. $31.7 \%$ agreed to tree planting, $26.3 \%$ resolved to reforestation as strategy, $18.3 \%$ addressed to combat deforestation, $15.4 \%$ talked about environmental auditing while $8.3 \%$ of the respondents stressed about enforcing law to curb illegal felling of trees. And that such strategy should be developed in order to promote the sustainable uses of forest resources in the study area.

\section{Conclusion}

Global environmental concern in the last five decades has harped on sustainability. The major problem of sustainable forest and forests products are the non- compliance to the rule of afforestation, and that is, if a tree is fell for any purpose, and not replaced for any reason the forests and their products will not last. The indiscriminate felling of tree and over-exploitation of the products in quest for food, timber and fuel wood without being marked should be avoided otherwise, the products would quickly run out and other generations would not benefit from. The advocacy for environmental resources consumption pattern show that it neither short-change the present generation nor be a disadvantage to the future generation which is the thrust of sustainable development. Having itemized the problem and the suggestion proffered, it is good to create awareness and environmental education as regard varying products, their uses and sustainability that would assist in the nation building and development.

\section{References}

[1] Adebayo, S. O. [2018]: In the Land of My Birth: Life Struggles and Survival, Ibadan, Afolabi Press Ltd: 140-174.

[2] Adebayo W. O. [2004]: Ecology of Natural Resources, AdoEkiti, Dunjoy Printer and Publisher.

[3] Adegboyega, E. R. [2014]: Geospatial Mapping for Environmental Resources Management and Sustainability in Ekiti State. An unpublished Ph.D Thesis, Submitted to the Department of Geography and Planning Sciences, Faculty of the Social Sciences, Ekiti State University, Ado-Ekiti. 
[4] Akande, J. A., [1994]: Environmental Problems Related to Forest Deforestation in Nigeria. Proceedings of 22nd Annual Conference for the Forest Association of Nigeria, Kano.

[5] Armanice, D [2017]: How to make millions in charcoal production in Nigeria. https://www.nairalandforum /nairaland.com how to make millions/....Access2214/2020.

[6] Babalola, F. D. and Opti, E. E. [2013]. Charcoal versus Domestic Cooling Fuels: Survey of Factor Influencing Consumption in Selected Households in Benue State. Journal of Sustainable Development of Africa, 15 [4], 25-37.

[7] Bamiro, O. M. and Ogunjobi, O. J. [2015]. Determinants of Household Energy Consumption in Nigeria: Evidence from Ogun State. Research Journal of Social Science and Management, 3 [2], 8-21.

[8] Bohnet, M. [1994]: Poverty Reduction through Help for Self Help, Economics, 49 [50]. Pp 99-110.

[9] Dobson, A. [2002]. Environmental and Ecologism in Barry, J. and E Frankland [Eds). International Encyclopedia of Environmental Politics, Routledge.

[10] Evan Mercer, D. and Soussan, J. [1986]. Fuel Wood Problems and Solutions 2012 - Catalyst. forum.org.uk content: infor@catalystforum.org.uk.

[11] FAO, [2010]. Forests and Energy, Regional Perspectives: Opportunities and Challenges for Forests and Forestry. African Forestry and Wildlife Commission.

[12] FAO [2015]: Global guideline for the restoration of degraded forest and landscape in dry Land: building resilience and benefiting livelihood by berament, $N$, Regato, $P$, and parlodry, $M$, forestry paper nos: 175. Rome, FAO of the United Nations.

[13] Fasona, M. J., Oloukoi, G., Olorunfemi, F. B., Elias, P. O. and Adedayo, V., [2014]: Natural Resource Management and Livelihoods in The Nigerian Savana, Ibadan, Penthouse Publications [Nig.]

[14] Fasuan, O. [2002]: Creation of Ekiti State: The Epic Struggle of a People, Ado-Ekiti, Industrial and Merchandised Nigeria Limited pp 1-10.

[15] Hewis J. [1993]. Agricultural Production in Ecyclopedia Botannica, London.

[16] Ike, D. N. [1996]: Poverty Alleviation in Nigeria. UBA Monthly Business and Economic Department.

[17] Iwena, O. A. [2008]: Essential Geography for Senior Secondary School, Ikeja, Lagos, TONAD Publisher. P 1-10, $55-60$.

[18] Obadan, M. I. [2004]: Analytical Framework for Poverty Reduction: Issue of Economic Growth versus Other Strategies. Selected Papers for the 1197 Annual Conference on Poverty Alleviation in Nigeria by the Nigerian Economic Society. University of Ibadan Press.

[19] Odihi, J. O. [1994]: Urban Agriculture in Maiduguri Rationla, Nature and Problems. A Paper Presented at a Seminar Organised by the Faculty of Management Science. University of Maiduguri.

[20] Omotoso, O. [2006]: "Rural Settlements Pattern". In Adebayo. W. O. [eds], Fundamentals of Human Geography, Adeyemo Publishing House, Akure, Nigeria.

[21] Onyeachi, A. U., Ibeanu, V. N., Eme, P. Z. and Ossai, O. C., [2013]: Nutrients and Pytochemical Composition of Formulated Diabetics Shaks Made from Two Nigerians Foods, Afzelina Africana and Detarium micocapium seed flour. Pakistan Journal of Nutrition 12 [2]: 108-113.

[22] Popoola, L. [2016]: Nigeria Loses 400,000 Hectares of Forest Annually, Punch Newspaper, Jan. 25 p 47.

[23] UNEP, [2012]. Towards a Green Economy, Pathways to Sustainable Development and Poverty Eradication. http://www.unep.org. Green Economy, Green Economy Report.

[24] Zaku, S. G. Kabir, A., Tukur, A. A. and Jumento, I. G. [2013]. Wood Fuel Consumption in Nigeria and Energy Ladder: A Review of Fuel Wood in Kaduna State. Journal of Energy and Alternative Fuels, 4 [5], 85-89. 